\title{
Tactical Behaviour in Soccer: Analysis of an Under-11 Team by the "GK3- 3GK” Test
}

\author{
I. Costa ${ }^{1,3, *}$, J. Garganta ${ }^{3,4}$, P. Greco, ${ }^{2}$, I. Mesquita ${ }^{3,4}$, D. Castelão ${ }^{3}$, E. Müller ${ }^{3}$, B. Silva ${ }^{3}$, \\ A. Rebelo ${ }^{3,4}$ and A. Seabra, ${ }^{3,4}$ \\ ${ }^{1}$ University Center of Belo Horizonte, UNI-BH, Belo Horizonte, MG-Brazil \\ ${ }^{2}$ Federal University of Minas Gerais, UFMG, Belo Horizonte, MG-Brazil \\ ${ }^{3}$ Faculty of Sport, University of Porto, FADEUP, Porto, Portugal \\ ${ }^{4}$ Centre of Research, Education, Innovation and Intervention in Sport, CIFI ${ }^{2} D, F A D E U P$, Porto, Portugal
}

\begin{abstract}
The aim of this study is to compare game principles performed by 18 youth soccer players taking into account the tactical principles of the game, the action's place and respective outcome. The sample comprised 763 tactical actions performed by soccer players from one Portuguese club. The test "GK3-3GK" was used to provide the evaluation of tactical actions according to ten basic tactical principles of soccer game. For data analysis it was used a descriptive analysis and chi-square $\left(\chi^{2}\right)$ test $(\mathrm{p} \leq 0.05)$. The results showed that players perform better the tactical actions related to the offensive principles than to the defensive principles. In conclusion, it is possible to assert that players have to improve, mainly, the performance of the "delay", "balance" and "defensive unity" principles.
\end{abstract}

Keywords: Soccer, Tactical Performance, Game Principles.

\section{INTRODUCTION}

Analysis of the tactical behavior in football is fully justified when three specific factors of the game are considered that are not always pondered by the supporters: 1) the majority of actions in the game happens without ball possession [1]; 2) players that have limited domain of the technical abilities can play football if they understand tactically the game [2]; 3) the lack of knowledge and an inefficacious tactical reasoning are decisive causes for the wrong execution of the technique ability [3]. Researchers have used Notational Analysis [4] and the Observational Methodology procedures [5] to get these information from the game.

With the objective to get further information about this subject the aim of this present study was to analyze the tactical behaviour of an Under-11 Soccer team by the "GK33GK" test.

\section{MATERIAL AND METHODS}

\section{Participants and Sample}

In the present study, 18 Under-11s Soccer players were analyzed. These players performed 401 defensive and 362 offensive tactical actions. Data from throw-ins, free kicks and situations where the player didn't move, were not analyzed.

\section{Applied Method}

Players performed a 4 minute small-sided game ( 3 vs. 3 with goalkeepers). The "GK3-3GK" test is designed in

\footnotetext{
*Address correspondence to this author at the Centro de Estudos em Cognição e Ação (CECA), Escola de Educação Física, Fisioterapia e Terapia Ocupacional da UFMG, Av. Presidente Antônio Carlos, 6627Pampulha, Belo Horizonte - Minas Gerais - Brazil; Cep: 31.310-250; Tel/Fax: 0XX (31) 3499-2325; E-mail: israelteoldocosta@gmail.com
}

a field of 36 meters length and 27 meters width. With the exception of the offside rule, all official Soccer rules were applied. The test aimed to evaluate the tactic actions performed by players (with and without the ball) attending on ten fundamental tactical principles of the game. Additionally, the test considered the place of action and the action outcome. Based on this information several indexes of performance were calculated, concerning tactical game principles, place of action and action outcome.

\section{Procedure}

The data for our study was attained in a Portuguese club with directors' permission. Prior to the test, a brief explanation of the objectives was given to the players. The teams were formed randomly and the players were wearing numbered vests in order to facilitate their identification. A thirtysecond period had been granted to familiarize them with the test and after which the game began.

\section{Materials}

The games were recorded with a digital camera PANASONIC NV - DS35EG. The digital videos were transferred to a laptop via cable and converted into "avi" files. Softwares Utilius VS and Soccer Analyser were used for data processing.

\section{Statistical Analysis}

Statistical procedures were done using SPSS for Windows ${ }^{\circledR}$, version 17.0. Descriptive analyses (frequency, means and standard-deviation) were carried out to characterize the sample. The normal distribution of the data was verified by the test of Kolmogorov-Smirnov and homogeneity of variances was assured by test of Levene. The analysis of 
variance (ANOVA) was used to compare the values of the performance indexes, concerning tactical actions and its errors and setting. The chi-square $\left({ }^{2} \kappa\right)$ with a significance level of $p<0.05$ was used verify the association between the frequency of the principles performed by the players [6]. The Kappa of Cohen coefficient was used to check inter- and intra-observers reliability.

\section{Reliability Analysis}

To determine the reliability of the observation, the testretest method was used to obtain the stability-reliability coefficient. Three observers were trained to review 218 tactical actions that represent $28.57 \%$ of the sample. This percentage is above the value of reference $(10 \%)$ recommended by the literature [7]. The results reveals an inter-observers agreement coefficient of 0.93 (standard-deviation $=0.01$ ), 0.88 (standard-deviation $=0.02$ ) and 0.89 (standard-deviation
$=0.02)$ and intra-observers agreement coefficient of 0.95 ( standard-deviation $=0.01), 0.89($ standard-deviation $=0.02)$ and 0.92 (standard-deviation $=0.02$ ). These values are above the conventional level of acceptance (0.61) [8].

\section{RESULTS AND DISCUSSION}

It was opted to display the data in the sequence of criteria evaluated by the Test: first presents information relative to the frequencies and percentage of errors of the actions by each principle, followed by the place where they were performed and, later, their action outcomes. Thus, Table 1 shows the principles, place of action and action outcomes from the "GK3-3GK", considering the number, percentage and error percentage performed by the players.

The highest values for the offensive phase are "Offensive Coverage" and "Width and Length". For the defensive phase

Table 1. Principles, Place of Action and Action Outcomes from the "GK3-3GK" Test

\begin{tabular}{|c|c|c|c|}
\hline & $\mathbf{N}$ & $\%$ & Error \%* \\
\hline \multicolumn{4}{|l|}{ Game Principles } \\
\hline Penetration & 49 & 6,4 & 16,3 \\
\hline Offensive Coverage & 100 & 13,1 & 08,0 \\
\hline Width and Length & 99 & 13,0 & 08,1 \\
\hline Depth Mobility & 40 & 5,2 & 07,5 \\
\hline Offensive Unity & 74 & 9,7 & 12,2 \\
\hline Delay & 67 & 8,8 & 59,7 \\
\hline Defensive Coverage & 9 & 1,2 & 22,2 \\
\hline Balance & 95 & 12,5 & 47,4 \\
\hline Concentration & 44 & 5,8 & 18,2 \\
\hline Defensive Unity & 186 & 24,4 & 32,3 \\
\hline Total & 763 & 100,0 & 25,0 \\
\hline \multicolumn{4}{|l|}{ Place of Action } \\
\hline \multicolumn{4}{|l|}{$\underline{\text {-Defensive Midfield }}$} \\
\hline Offensive actions & 159 & 20,8 & \\
\hline Defensive actions & 279 & 36,6 & \\
\hline \multicolumn{4}{|l|}{ - Offensive Midfield } \\
\hline Offensive actions & 203 & 26,6 & \\
\hline Defensive actions & 122 & 16,0 & \\
\hline \multicolumn{4}{|l|}{ Action Outcomes } \\
\hline \multicolumn{4}{|l|}{ - Offensive phase } \\
\hline Shot at goal & 37 & 4,9 & \\
\hline Keep possession of the ball & 250 & 32,7 & \\
\hline Loss of ball possession & 75 & 09,8 & \\
\hline \multicolumn{4}{|l|}{ - Defensive phase } \\
\hline Regain the ball possession & 77 & 10,1 & \\
\hline Ball possession of the opponent & 289 & 37,9 & \\
\hline Shot at goal of the opponent & 35 & 4,6 & \\
\hline
\end{tabular}

*Error percentage (Error \%) refer to the number of actions done without success. 
the upper values are "Balance" and "Defensive Unity". It verifies that the lowest frequency is for the "Defensive Coverage" principle. It can be attributed to the positioning and movement of players in the offensive phase that blocking defensive actions to the adversary marked for the player in "delay".

Regarding the error percentage, it checks the highest values for the "Delay", "Balance" and "Defensive Unity" principles. These three principles together are responsible for $75.9 \%$ of all the errors related to the execution of all principles. These results illustrates more difficult of players to execute tactical actions concerning the defensive phase.

Table 1 also shows highest frequency to offensive actions executed on the defensive midfield. This result can be justified by the defensive fragility of team, who positions its marking players more back on the field to get numerical superiority in relation to the opponent. The team presents an offensive strategy based on the ball possession with realization of pass in the defensive midfield in order to organize its players before advance to the offensive midfield. This statement can be supported by the results of the action outcomes where it observes high value to "keep possession of the ball", reinforced by the low frequency of "Regain the ball possession".

Table 2 shows the performance indexes for each player of the team. All indexes were calculated considering the principles, phases of the game (offensive and defensive) and game. The values put on display in the Table $\mathbf{2}$ show that the players are heterogeneous concerning their performance. These results illustrates that tactical performances are differ- ent between all players as offensive and defensive principles as games phases.

Comparing the performance indexes of the players with the mean of team for each of the tactical principles, it observes that three players had gotten lowest indexes for two principles. Another seven players had gotten lowest indexes for three or four principles, and seven players had for five or six principles. Only one player got lowest index for seven principles. These results support the heterogeneities of players performance.

Analyzing the Tactical Performance Index of the Offensive Phase (IPTO) and the Tactical Performance Index of the Defensive Phase (IPTD) of each player, it notes that only three players have higher defensive efficiency than offensive, what can be one of the justifications for the difficulty presented for the players in carrying defensive tactical actions. It also observes that six players had gotten indexes below of the mean of the team during the offensive phase and seven had gotten inferior indexes during the defensive phase.

In fact, the players have more facility to execute tactical actions related to the offensive principles than defensive principles. This result is more evident when it compares the mean of IPTO (9.9) with the mean of IPTD (6.7).

Regarding the Tactical Performance Index of the Game IPTJ - it is possible to observe that eight players had gotten lower means than the team. From these, three had gotten inferior mean in both phases of the game (offensive and defensive).

Therefore, it is possible to conclude that the players analyzed have different levels of performance to the offensive

Table 2. Players Performance Indexes for Each Game Principle and Phase

\begin{tabular}{|c|c|c|c|c|c|c|c|c|c|c|c|c|c|c|c|c|c|c|c|}
\hline Variables & 1 & 2 & 3 & 4 & 5 & 6 & 7 & 8 & 9 & 10 & 11 & 12 & 13 & 14 & 15 & 16 & 17 & 18 & $\mathrm{M} \pm \mathrm{sd}$ \\
\hline Offensive Coverage & 11,3 & 4,1 & 3,0 & 14,8 & 11,2 & 8,5 & 9,6 & 12,0 & 9,4 & 12,0 & 9,6 & 6,5 & 8,8 & 10,2 & 10,7 & 2,0 & 15,2 & 12,0 & $\mathbf{9 , 5} \pm 3,6$ \\
\hline Depth Mobility & 16,0 & - & 7,0 & 9,7 & 16,0 & - & 2,0 & 13,1 & 10,0 & 8,7 & - & 8,0 & 11,2 & - & 10,7 & - & - & 14,3 & $\mathbf{1 0 , 6} \mathbf{6} \pm, 0$ \\
\hline Offensive Unity & 13,3 & 9,3 & 4,0 & 16,0 & 6,3 & 13,0 & 11,4 & 8,0 & 16,8 & 20,0 & 2,5 & 7,0 & 8,0 & 10,8 & 13,0 & 14,8 & 3,0 & 16,0 & $\mathbf{1 0 , 7} \mathbf{7}, 1$ \\
\hline$\underline{\text { IPTO }}$ & 12,3 & 6,4 & 4,7 & 12,6 & 10,3 & 11,4 & 11,3 & 11,9 & 11,7 & 8,8 & 7,9 & 4,5 & 10,4 & 9,4 & 10,2 & 11,7 & 12,5 & 10,6 & $9,9 \pm 2,5$ \\
\hline Delay & 11,3 & 6,3 & 4,0 & - & 4,0 & 5,0 & 11,7 & 15,0 & 7,3 & 4,5 & 7,0 & 7,7 & 6,0 & 7,0 & 10,7 & 8,0 & 4,0 & 4,0 & $\mathbf{7 , 3} \pm 3,2$ \\
\hline Defensive Coverage & - & 8,0 & - & - & - & - & - & - & 20,0 & 8,0 & - & - & - & 4,0 & 20,0 & 3,0 & 13,0 & 8,0 & $\mathbf{1 0 , 5} \pm 6,6$ \\
\hline Defensive Unity & 10,0 & 8,0 & 4,7 & 7,8 & 6,2 & 6,5 & 5,8 & 5,5 & 8,5 & 3,9 & 6,9 & 6,9 & 8,2 & 7,0 & 6,2 & 7,9 & 6,6 & 6,0 & $\mathbf{6 , 8} \pm 1,5$ \\
\hline$\underline{\text { IPTD }}$ & 9,4 & 6,7 & 5,6 & 9,0 & 4,0 & 5,8 & 6,4 & 7,1 & 8,2 & 5,2 & 7,1 & 6,7 & 7,5 & 5,4 & 7,1 & 7,2 & 7,3 & 5,7 & $6,7 \pm 1,3$ \\
\hline IPTJ & 11,1 & 6,6 & 5,4 & 11,6 & 6,8 & 8,4 & 9,6 & 10,3 & 10,5 & 6,3 & 7,4 & 6,2 & 9,1 & 7,8 & 8,9 & 8,7 & 9,1 & 7,2 & $8,4 \pm 1,8$ \\
\hline
\end{tabular}

M - Mean. sd - standard-deviation. IPTO- Tactical Performance Index of the Offensive Phase (Calculated by the means of all the tactical actions related with the offensive principles). IPTD - Tactical Performance Index of the Defensive Phase (Calculated by the means of all the tactical actions related with the defensive principles). IPTJ - Índice Tactical Performance Index of the Game (Calculated by the means of all tactical actions executed).

PS.: With highlight (italics + grey) all means of players lower than mean of the team. 
and defensive principles. Based on this statement and the values of offensive and defensive phases of the game, it is reasonable to conclude that they indicate that the team has to improve, mainly, the performance of the "Delay", "Balance" and "Defensive Unity" principles.

\section{ACKNOWLEDGEMENT}

Supported by the Programme AlBan, the European Union Programme of High Level Scholarships for Latin America, scholarship n E07D400279BR”.

\section{REFERENCES}

[1] Garganta J. Modelação táctica do jogo de futebol - estudo da organização da fase ofensiva em equipas de alto rendimento. [Tese Doutoramento]. Porto: Universidade do Porto 1997.
[2] Oslin J, Mitchell S, Griffin L. The Game Performance Assessment Instrument (GPAI): development and preliminary validation. $\mathbf{J}$ Teach Phys Educ 1998; 17: 231-43.

[3] Teodorescu L. Problemas de teoria e metodologia nos jogos desportivos. Melo de Carvalho A, Ed. Lisboa: Livros Horizontes Lda 1984.

[4] Hughes C, Franks I. Notational analysis of sport. London: E. \& F.N Spon 1997.

[5] Anguera M, Blanco A, Losada J, Hernández A. La metodología observacional en el deporte: conceptos básicos. Lecturas: EF y Deportes. Rev Digit 2000; 5 (24). Available at: http//:www.efdeportes. com

[6] Pestana MH, Gageiro JN. Análise de dados para ciências sociais: a complementaridade do SPSS. $3^{\text {a }}$ ed. Lisboa: Lisboa Edições Sílabo 2003.

[7] Tabachnick B, Fidell L. Using multivariate statistics. New York: Harper \& Row Publishers 1989.

[8] Landis JR, Koch GC. The measurement of observer agreement for categorical data. Biometrics 1977; 33: 1089-91.

(C) Costa et al.; Licensee Bentham Open.

This is an open access article licensed under the terms of the Creative Commons Attribution Non-Commercial License (http://creativecommons.org/licenses/by-nc/3.0/) which permits unrestricted, non-commercial use, distribution and reproduction in any medium, provided the work is properly cited. 